\title{
Leiomyoma of the vagina: Report of two cases
}

\author{
Vajina leiyomiyomu: iki olgu sunumu
}

\author{
Bulent Yilmaz ${ }^{*}$, Orcun Ozdemir ${ }^{*}$, Osman Sevket ${ }^{* * *}$, Zehra Sekerci' ${ }^{* * *}$, Nur Buyukpinarbasilit ${ }^{* * *}$, \\ Sefa Kelekci**
}

\begin{abstract}
*Numune Eğitim ve Araştırma Hastanesi, Kadın Hastalıkları ve Doğum Kliniği, Adana
** Izmir Katip Çelebi Üniversitesi, Kadın Hastalıkları ve Doğum Anabilim Dalı, İmir

*** Bezmialem Vakıf Üniversitesi, Kadın Hastalıkları ve Doğum Anabilim Dalı, İstanbul

**** Bezmialem Vakıf Üniversitesi, Patoloji Anabilim Dalı, İstanbul
\end{abstract}

\begin{abstract}
Leiomyoma of the vagina is an uncommon neoplasm, but they are the most common mesenchymal tumors of the vagina. In this article, we present two cases of vaginal leiomyoma at 39 years old and 75 years old. The tumors were easily excised totally with a vertical incision through the vaginal wall with the vaginal approach. Surgical excision is the most chosen treatment of these tumors. A urethral catheter may aid in dissection and help to prevent urethral injury.
\end{abstract}

Pam Med J 2014;7(1):79-82

Key words: Leiomyoma of the vagina, surgical excision, histological examination.

\section{Özet}

Vajinadan kaynaklanan leiyomiyom nadir bir tümördir, ancak vajinanın mezenkimal tümörlerinin ensık görülenidir. Bu makalede, vajinal Leiyomiyomu olan 39 ve 75 yaşında iki olgu sunuldu. Vajinal duvar boyunca vertikal bir kesi yapılarak bu tümörler total olarak kolayca çıkarılmıştır. Cerrahi eksizyon bu tümörlerin tedavisinde sıklıkla seçilen yöntemdir. Diseksiyonu kolaylaştırmak ve üretra yaralanmasını önlemek için bir üretral kateter kullanılabilir.

Pam Tıp Derg 2014;7(1):79-82

Anahtar sözcükler: Vajinal Leiyomiyom, cerrahi eksizyon, histolojik inceleme.

\section{Introduction}

Neoplasms of the vagina are not frequent, and most are benign. Leiomyoma and fibroma are rare tumors. They are the most common mesenchymal tumors of the vagina. The tumors may be found in any location within the vagina, but they are most commonly located on the anterior wall, and least commonly on the lateral vaginal wall. Their size varies from 0.5 to $15 \mathrm{~cm}$ [1]. We report two cases of vaginal leiomyoma which could not be diagnosed clinically but only on histological examination.

\section{Case 1}

A-39- year-old multigravid woman presented to the gynecology outpatient clinic, with a10-day history of left groin pain, discharge, dysparunea. She had no urinary or defecation difficulties. She had five vaginal deliveries, one miscarriage and two legal abortions. Otherwise her general medical history was unremarkable. There was a round-shaped, mobile, painless mass, about $2 \mathrm{~cm}$, on the left lateral vaginal wall on gynecologic examination. There was no cystourethrocele, rectocele, enterocele or uterovaginal prolapse. Chronic cervititis was detected. Uterus and adnexia was

Osman Şevket

Yazışma Adresi: Bezmialem Vakıf Üniversitesi, Kadın Hastalıkları ve Doğum AD., İstanbul e-mail: sevketosman@gmail.com 
unremarkable. Under general anesthesia the mass was easily excised totally with a vertical incision through the left lateral vaginal wall with vaginal approach (Figure $1 \mathrm{~A}$ and $1 \mathrm{~B}$ ). Singlelayer closure was performed and she was discharged without further symptoms.

Gross pathological examination of the vaginal mass showed a $2 \times 2 \times 1.5 \mathrm{~cm}$ oval, whitish, firm nodule and there was no area of hemorraghia, necrosis, or degeneration on the surface of it. Histologic examination showed the mass was not encapsulated, consisted of a uniform population of spindle smooth muscle cells arrayed in an indistinct fascicular pattern, with eosinophilic cytoplasm. There was no celluler atypia or mytotic activity (Figure 1C).

\section{Case 2}

A 75 years old multigravid woman presented to the gynecology outpatient clinic with a history of a palpable mass hanging out of the vagina. She had no urinary or defecation difficulties. She had five vaginal deliveries. Her general medical history was unremarkable. There was total uterovaginal prolapsus and a roundshaped, mobile, painless mass, about $2 \mathrm{~cm}$,

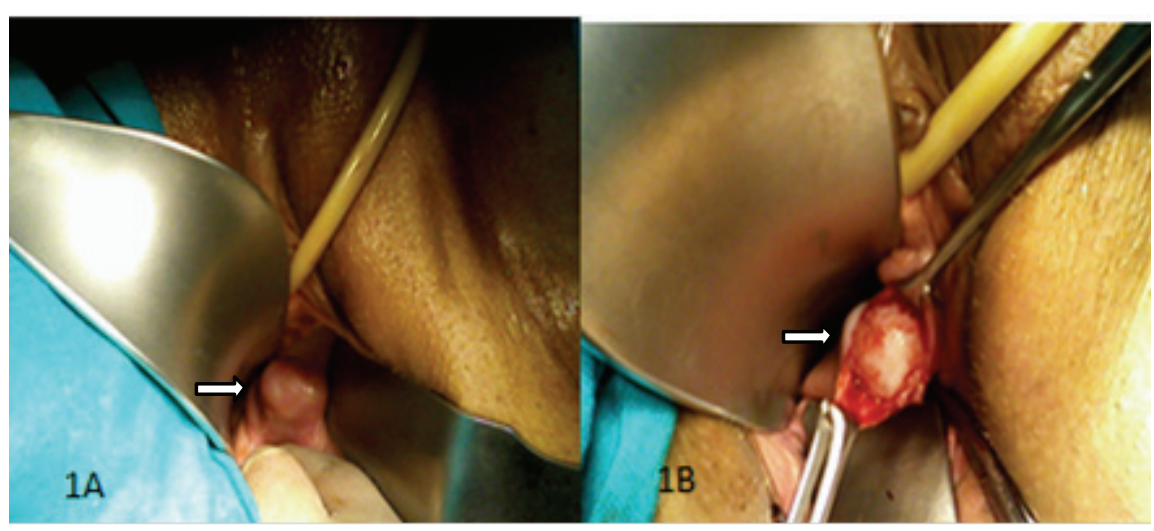

Fig. 1A. Gross appearance of the lesion at the left lateral vaginal wall (arrow). 1B. Appearance of leiomyoma while dissection of the vaginal wall (arrow).

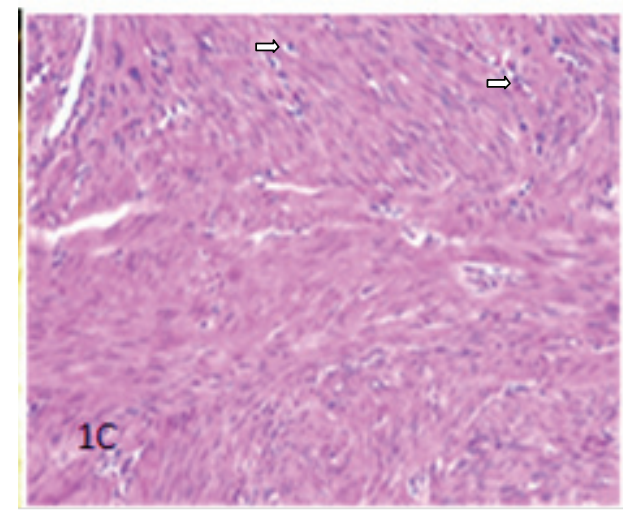

Fig. 1C. Vaginal leiomyoma with spindle cells (arrow). (H\&E)

on the anterior vaginal wall on gynecologic examination. Uterus and adnexia was unremarkable. Under spinal anesthesia after vaginal hysterectomy, the mass was easily excised totally with a vertical incision through the anterior vaginal wall with vaginal approach and cystocele was repaired. Single-layer closure was performed and she was discharged without further symptoms.
Gross pathological examination showed a vaginal mass of $1,8 \times 1 \times 0,8 \mathrm{~cm}$ size. The cut surface was white, firm and rubbery texture composed of whorled bundles. Microscopic examination revealed fusiform smooth muscle cells with abundant pink cytoplasm and spindleshaped nuclei (Figure 2A). The chromatin was uniformly dispersed and nucleoli was small and inconspicuous. Mitotic figures were rare (Figure 2B). 


\section{Discussion}

Vaginal leiomyomas are benign smooth muscle tumors in the vagina, and extremely rare $[2,3]$. But uterine leiomyomas are common and may present clinically in $20-30 \%$ of females. In fact $75 \%$ of women have these benign tumors following careful histologic examination of the uterus [4]. Some authors think that vaginal leiomyomas develop from deeply penetrating uterine leiomyomas which subsequently
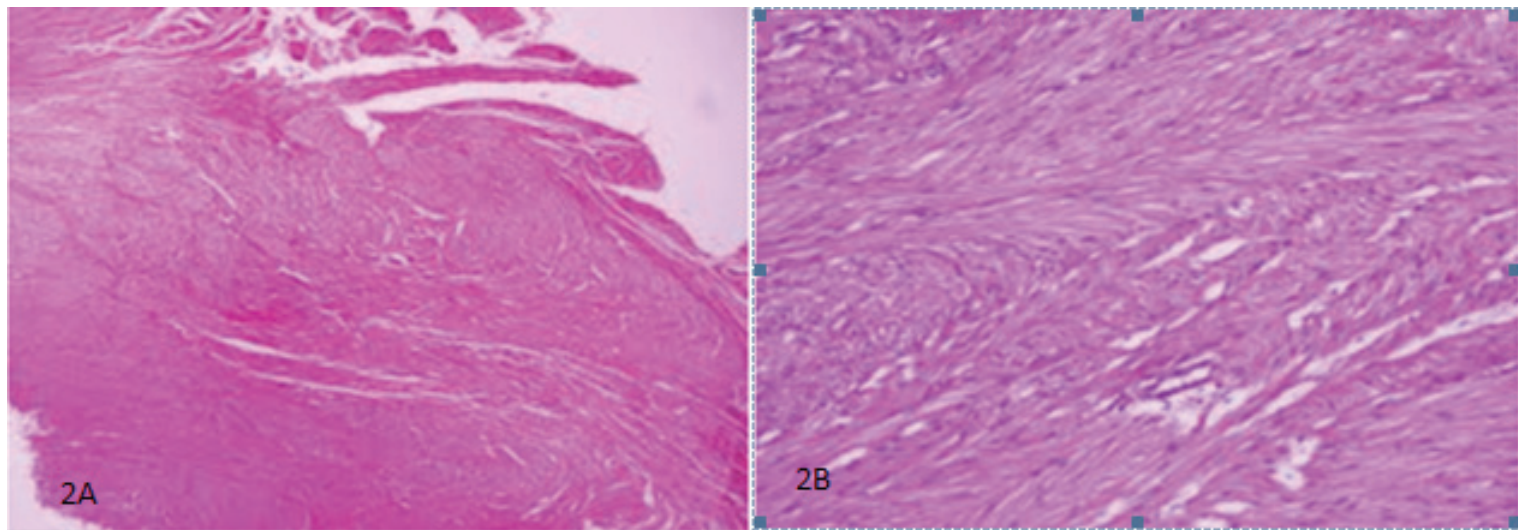

Fig. 2A. Vaginal leiomyoma with spindle cells. (H-EX10), 2B. Vaginal leiomyoma with spindle cells. (H-EX400).

become detached from the uterus. And some of the others postulate that they arise from vascular smooth muscle or embryonal cell rests within the vagina $[5,6]$.

These tumours are most often found in Caucasian women [7]. Since the first report by Denys de Leyden in 1733, approximately 300 cases of vaginal leiomyoma have been reported worldwide. Bennett and Ehrlich found only nine cases in 50,000 surgical specimens and only one case in 15,000 autopsies reviewed at Johns Hopkins Hospital [8].

Leiomyoma of the vagina occurs most frequently between the ages of 35 and 50 . Though the tumor begins at a much earlier age, slow growth characteristic of the tumor and the good distensibility of the vagina results in production of symptoms and awareness of the mass only around the age of $40[3,9]$.

Usually the tumor is located in the anterior vaginal wall, and less commonly in the lateral walls like our case [9]. No correlation is shown between the occurrence of leiomyomas in the vagina and any other sites like the uterus [3]. These tumors generally produce mobile, painfree and well defined bordered masses. Most vaginal fibromyomata vary between 1 and $5 \mathrm{~cm}$, but some may reach $10 \mathrm{~cm}$ in size and weigh up to $1450 \mathrm{~g}$. A careful histological examination is essential to exclude malignancy since malignant transformation is more common in extra uterine leiomyomas [9]. A 9.1\% incidence of sarcoma, in a series of 11 cases with vaginal leiomyoma was reported $[3,10]$.

Vaginal leiomyomas have variable clinical presentations such as; pelvic pain, bladder outlet obstruction, constipation, difficulty with coitus, dyspareunia or frequency, urgency, dysuria, urinary retention and incontinence [9-12]. Patients are commonly asymptomatic in the early stages [1]. Ulceration with subsequent necrosis, purulent discharge and bleeding are the other rare symptoms $[3,10]$.

Vaginal surgical enucleation is the preferred treatment, but careful histological examination is required to exclude malignancy. A urethral catheter may aid in dissection and help prevent urethral injury.

Conflict of Interest: The authors report no conflict of interest.

\section{References}

1. Sesti F, Marca L, Pietropolli A, Piccione E. Multiple leiomyomas of the vagina in a premenopausal woman. Arch Gynecol Obstet 2004;270:131-132.

2. Pulfus E, Newcomer J. Vaginal wall mass. Obstet Gynecol Surv 1999;54:149-150. 
3. Sangwan K, Khosla AH, Hazra PC. Leiomyoma of the vagina. Aust NZ J Obstet Gynaecol 1996;36:494-495.

4. Spellacy WN. Uterine leiomyoma. In: Scott JR, Di Saia PJ, Hammond Cr, Spellacy WN, ed. Danforth's obstetrics and gynecology. 8 th Lippincott, Philadelphia, 1999;857-864.

5. Campbell EW, Gislason GI. Benign mesothelial tumors of the urinary tract: review of the literature and report of a case of leiomyoma. J Urol 1953;70:733.

6. Gorlin RJ, Koutlas IG. Multiple schwannomas, multiple nevi, and multiple vaginal leiomyomas: a new dominant syndrome. Am J Med Genet 1998;78:76-81.

7. Meniru GI, Wasdahl D, Onuora CO, Hecht BR, Hopkins MP. Vaginal leiomyoma co-existing with broad ligament and multiple uterine Leiomyomas. Arch Gynecol Obstet 2001;265:105-107.
8. Bennett HG Jr, Ehrlich MM. Myoma of the vagina. Am J Obstet Gynecol 1941;42:314-320.

9. Haberal A, Gunes M, Kayıkcıoglu F, Ozturkoglu E, Katas B, Demir OF. Leiomyoma of the Vagina: A Case Report. J Turkish German Gyecol Assoc 2005;6:52-53.

10. Dhaliwal LK, Das I, Gopalan S. Recurrent leiomyoma of the vagina. Int J Gynecol Obstet 1992;37:281-283.

11. Shimada K, Ohashi I, Shibuya H, Tanabe F, Akashi T. MR imaging of an atypical vaginal leiomyoma. AJR 2002;178:752-754.

12. Ruggieri AM, Brody JM, Curhan RP. Vaginal leiomyoma: a case report with imaging findings. J Reprod Med 1996;41:875-877. 